\title{
PENGARUH PERFEKSIONISME TERHADAP PROKRASTINASI AKADEMIK PADA MAHASISWA YANG SEDANG MENGERJAKAN SKRIPSI DI FAKULTAS PSIKOLOGI UIN SUNAN GUNUNG DJATI BANDUNG
}

\author{
Titih Srantih \\ UIN Sunan Gunung Djati Bandung, Jl. A.H. Nasution 105 \\ e-mail:tsrantih@gmail.com
}

\begin{abstract}
Academic procrastination particularly happens to college students who are working on their thesis is assumed to be influenced by the attitude of their perfectionism. The purpose of this study is to determine how perfectionism has influence on the academic procrastination of the students who are doing thesis at the Faculty of Psychology UIN Sunan Gunung Djati Bandung. The study had conducted on the population of students who are working on a thesis in total 38 people. The design used was a non-experimental design with causality method. Measuring instruments used the Almost Perfect Scale Revised from Snaley (1992) and Procrastination Student Assessment Scale developed by Solomon and Rothblum (1984) with some adaptations. Technical analysis of the data using simple regression analysis with the result that the determination coefficient of influence perfectionism to academic procrastination is $R 2=0.065$. The results of the $t$ test, $t=1.582$ $<$ table $=1.684$, so it can be concluded that there is no significant effect of perfectionism to the academic procrastination of students who are working on a thesis.
\end{abstract}

Keywords: procrastination, perfectionism, doing thesis

\begin{abstract}
Abstrak
Prokastinasi akademik khususnya yang terjadi pada mahasiswa yang sedang mengerjakan skripsi diasumsikan sebagai akibat dari sikap perfeksionisme mereka. Tujuan dari penelitian ini adalah untuk mengetahui seberapa besar pengaruh perfeksionisme terhadap prokrastinansi akademik pada mahasiswa yang sedang skripsi di Fakultas Psikologi UIN Sunan Gunung Djati Bandung. Studi dilakukan kepada populasi mahasiswa yang sedang mengerjakan skripsi yang berjumlah 38 orang. Rancangan yang digunakan adalah rancangan non-eksperimental dengan metode kausalitas. Alat ukur yang digunakan Almost Perfect Scale Revised dari Snaley (1992) dan Procrastination Assessment Scale Student yang dikembangkan oleh Solomon dan Rothblum (1984) dengan beberapa adaptasi. Teknis analisis data menggunakan analisis regresi sederhana dengan hasil yakni besarnya pengaruh atau koefisien determinasi perfeksionisme terhadap prokrastinasi akademik pada mahasiswa yang sedang mengerjakan skripsi $\mathrm{R}^{2}=0.065$. Hasil uji $\mathrm{t}$, $\mathrm{t}_{\text {hitung }}=1,582<$ $\mathrm{t}_{\text {tabel }}=1,684$, sehingga dapat disimpulkan bahwa tidak terdapat pengaruh yang signifikan antara perfeksionisme dengan prokrastinasi akademik pada mahasiswa yang sedang mengerjakan skripsi di Fakultas Psikologi UIN SGD Bandung.
\end{abstract}

Kata Kunci : Prokrastinasi, perfeksionisme, dan pengerjaan skripsi

\section{PENDAHULUAN}

Mahasiswa merupakan peserta didik yang terdaftar dan sedang menempuh proses pendidikan di Perguruan Tinggi. Pada umumnya mahasiswa berusia antara 18-24 tahun atau berapa pada tahap dewasa awal (Hurlock, 1980). Mahasiswa merupakan masa yang memasuki masa dewasa, pada masa tersebut mahasiswa memiliki tanggung jawab terhadap masa perkembangannya, termasuk memiliki tanggung jawab terhadap kehidupannya untuk memasuki masa dewasa. Individu pada tahap dewasa awal berada pada fase pencapaian prestasi (achieving stage), 
yaitu suatu fase yang melibatkan penerapan intelektualitas pada situasi yang memiliki konsekuensi besar dalam mencapai tujuan jangka panjang, seperti pencapaian karir dan pengetahuan (Schaie dalam Papalia, 2002). Bidang vokasional atau pendidikan menjadi sangat penting pada fase ini karena melalui bidang tersebut seorang dewasa mampu mengaktualisasikan fungsi intelektualitasnya dalam bidang yang ia dalami.

Semakin tinggi tingkat pendidikan maka akan semakin banyak tanggung jawab yang perlu dilaksanakan. Dalam tingkatan pendidikan baik itu SD, SMP atau SMA syarat kelulusan yang harus dipenuhi hanya dengan mengikuti ujian tertulis, namun di Perguruan Tinggi syarat kelulusan yang harus dipenuhi oleh seorang mahasiswa adalah dengan membuat karya ilmiah yang biasa disebut dengan skripsi.

Skripsi adalah karya ilmiah yang diwajibkan sebagai bagian dari persyaratan pendidikan akademis di Perguruan Tinggi. Semua mahasiswa yang menempuh pendidikan di Perguruan Tinggi diwajibkan untuk mengambil mata kuliah skripsi karena merupakan prasyarat untuk memperoleh gelar akademisnya sebagai sarjana. Tuntutan dan tugas keharusan tersebut dimaksudkan agar mahasiswa mampu menerapkan ilmu dan kemampuan sesuai disiplin ilmu yang dimiliki ke dalam kenyataan yang dihadapi. Menyusun skripsi secara tidak langsung merupakan suatu penyesuaian diri dari mahasiswa yang terbiasa mendapatkan materi dari dosen dan buku, menjadi manusia yang harus menceriterakan suatu karya ilmiah atau menceriterakan suatu peristiwa secara ilmiah dan terstruktur. Ada beberapa penelitian yang mengangkat tema tentang fenomena yang muncul pada mahasiswa yang sedang menyusun skripsi.

Menurut Michelle (2004) memaparkan dalam risetnya bahwa mahasiswa dapat mengalami stress dan cemas akibat kesulitan-kesulitan dalam pengerjaan skripsi, seperti kesulitan menentukan latar belakang masalah, teori dan metodologi, ketakutan menghadapi dosen, jenuh, malas dan lain-lain. Masih dalam penelitiannya, umumnya mahasiswa diberikan waktu untuk menyelesaikan skripsi dalam jangka waktu satu semester atau kurang dari enam bulan (Lasmono dkk, 2008). Namun kenyataan masih banyak mahasiswa yang memerlukan waktu lama untuk mengerjakan skripsinya. Fenomena ini dijumpai salah satunya di fakultas Psikologi UIN Bandung, diperoleh berdasarkan data dari bagian akademik dan kemahasiswaan, masih banyak mahasiswa di Fakultas Psikologi UIN yang terhambat kelulusannya dikarenakan sulitnya dalam penyelesaian skripsi. Hal ini menjdi salah satu faktor penghambat untuk dapat lulus tepat waktu.

Berdasarkan data yang diperoleh dari bagian akademik dan kemahasiswaan fakultas Psikologi, rata-rata mahasiswa Psikologi UIN menyelesaikan studinya antara 4,5 tahun sampai 5 tahun. Angkatan 2005 yang mampu menyelesaikan 4 tahun hanya 2 orang, 4,5 tahun hanya 7 orang dan sisanya mencapai 5 tahun bahkan sampai 6 tahun. Angkatan 2006 yang mampu menyelesaikan 4 tahun hanya 4 orang, yang menyelesaikan 4,5 hanya sampai 12 orang. Angkatan 2007 yang lulus 4 tahun berjumlah 7 orang, sehingga terlihat hanya kurang dari $10 \%$ mahasiswa psikologi yang dapat lulus tepat waktu dengan jangka waktu pembuatan skripsi kurang lebih sampai enam bulan. Hal ini memungkinkan ada terjadinya penundaan pengerjaan skripsi atau terjadinya prokrastinasi. Adapun data Kelulusan yang diperoleh dari bagian akademik dan kemahasiswaan fakultas Psikologi UIN sebagai berikut: 

Diagram 1.1 Daftar kelulusan
mahasiswa Fakultas Psikologi

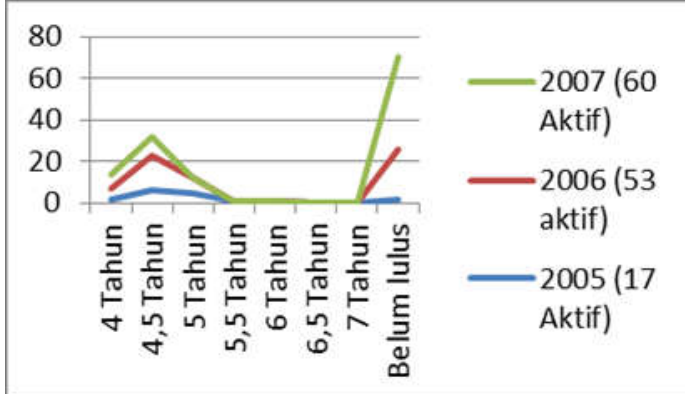

(sumber: bagian akademik dan kemahasiswaan Fakultas Psikologi Bulan Januari 2012)

Sedangkan data mahasiwa yang sedang mengerjakan skripsi, sebagai berikut:

Tabel 1.1 daftar mahasiswa yang sedang mengerjakan skripsi

\begin{tabular}{cccc}
\hline $\begin{array}{c}\text { Angkatan } \\
\text { Tahun }\end{array}$ & $\begin{array}{c}\text { Sedang } \\
\text { mengerjakan } \\
\text { skripsi }\end{array}$ & \multicolumn{2}{c}{$\begin{array}{c}\text { Tahapan dalam } \\
\text { pengerjaan skripsi }\end{array}$} \\
\cline { 3 - 4 } & & $\begin{array}{c}\text { Pra } \\
\text { seminar } \\
\text { (usulan } \\
\text { penelitian) }\end{array}$ & $\begin{array}{c}\text { Sudah } \\
\text { seminar }\end{array}$ \\
\hline 2005 & 2 & - & 2 \\
\hline 2006 & 20 & 11 & 9 \\
\hline 2007 & 35 & 9 & 26 \\
\hline Jumlah & 57 & 20 & 37 \\
\hline
\end{tabular}

(sumber: bagian akademik dan kemahasiswaan Fakultas Psikologi Bulan Januari 2012)

Diperoleh data berdasarkan hasil wawancara yang dilakukan kepada mahasiswa yang sedang menyusun skripsi, baik itu praseminar maupun yang sudah seminar, mengatakan bahwa alasan tertundanya pengerjaan skripsi karena 2 faktor. Faktor eksternal dan faktor internal. Faktor eksternal mencakup susahnya literatur juga dukungan yang ada dirasakan kurang. Sedangkan faktor internal rasa malas, malu bertemu dosen pembimbing karena takut dimentahkan lagi tentang pembahasan skripsinya, tidak bisa mengatur waktu, kurang paham terhadap materi, adanya masalah pribadi dan keyakinan negatif akan diri sendiri yang tercermin dari pernyataan "saya sulit untuk memulai".

Hambatan-hambatan yang dirasa-kan ketika penyusunan skripsi ini membuat mereka menjadi malas untuk mengerjakan skripsi dan cenderung melakukan prokastinasi. Di Fakultas Psikologi UIN Bandung, 2 tahun sebelumnya telah dilakukan penelitian tentang prokrastinansi akademik yang dihubungkan dengan motivasi berprestasi. Hasilnya menunjukan bahwa tidak terdapat hubungan antara prokrastinasi dengan motivasi berprestasi. Dalam penelitian ini memang berdeda dengan hipotesis yang dikaji, hal ini bisa terjadi karena berbagai faktor lain, baik dari peneliti ataupun proses penelitiannya. Sehingga prokras-tinasi akademik di wilayah Fakultas Psikologi masih menjadi fenomena menarik yang harus dikaji lebih.

Fenomena prokrastinansi terjadi di bidang aspek kehidupan, salah satunya di bidang akademik. Tuckman (2002) mendefinisikan prokrastinasi sebagai ketidakmampuan pengaturan diri yang mengakibatkan dilakukannya penundaan pekerjaan yang seharusnya dapat berada dibawah kendali atau penguasaan orangorang tersebut (dalam Lasmono dkk, 2008). Solomon dan Rothblum (1984) pada penelitian prokrastinasi yang kebanyakan dilakukan pada mahasiswa ditemukan bahwa 50\% sampai dengan 90\% terjadi prokrastinasi akademik pada mahasiswa.

Menurut Ferrari (1995) menemukan bahwa sekitar $15 \%$ sampai dengan $20 \%$ usia dewasa termasuk dalam keadaan prokrastinasi kronis. Hal ini menunjukkan bahwa begitu banyak mahasiswa yang melakukan prokrastinasi, padahal mahasiswa adalah penerus bangsa yang diharapkan kelak dapat memajukan bangsa ini. Menunda merupakan hal yang dianggap wajar dan sering dilakukan oleh banyak orang. Akan tetapi perilaku menunda-nunda waktu dan pekerjaan 
mempunyai dampak yang cukup serius antara lain mampu menurunkan tingkat produktifitas seseorang, dan lebih lanjut kemudian merusak mental dan etos kerja seseorang. Prokrastinasi juga akan mengakibatkan rendahnya kualitas sumber daya manusia itu sendiri.

Pelaku prokrastinasi (prokrastinator) cenderung melakukan prokrastinasi karena adanya rasa takut akan gagal, tidak suka pada tugas yang diberikan, menentang dan melawan kontrol, mempunyai sifat ketergantungan dan kesulitan membuat keputusan (Solomon dan Rothblum, 1984). Ketakutan yang berlebihan untuk gagal, seseorang menunda-nunda mengerjakan tugas sekolahnya karena takut jika gagal menyelesaikan tugas. Seseorang melakukan prokrastinasi disebabkan oleh adanya dua faktor yaitu faktor psikis dan faktor fisik. Faktor psikis diantaranya adalah rendahnya rasa percaya diri, keputusasaan, kurang konsisten, kecemasan, dan keinginan untuk mendapatkan hasil yang terbaik dengan menunda. Faktor fisik yaitu adanya ketidak mampuan seseorang untuk mengontrol stimulus dari luar, sehingga menyebabkan terjadinya prokrastinasi. Menurut Knaus (2002) seseorang dikatakan melakukan prokrastinasi apabila ia menunjukkan ciri-ciri antara lain takut gagal, impulsif, perfeksionis, pasif dan menunda-menunda sehingga melebihi tenggat waktu.

Pada saat mahasiswa yang sedang menyusun skripsi memiliki batas waktu yang ia rancang sendiri dan ternyata ia tidak mematuhinya sehingga berdampak pada perpanjangan penyelesaian skripsi, hal ini disebut dengan prokrastinasi tugas skripsi yaitu perilaku untuk menunda memulai maupun mengerjakan kinerja secara keseluruhan, lebih memilih untuk melakukan aktivitas lain yang tidak berguna, sehingga kinerja menjadi terhambat, tidsak menyelesaikan tugas tepat waktu, serta sering terlambat dalam menghadiri pertemuan-pertemuan (Solomon dan Rothblum, 1984).
Dari fenomena yang terjadi di fakultas Psikologi UIN Bandung, terlihat bahwa faktor internal yang lebih menonjol untuk mereka melakukan prokrastinasi, salah satunya keyakinan negatif akan diri sendiri. Hal ini tercermin pada munculnya rasionalisasi . Rasionalisasi merupakan pikiran yang membantu prokrastinator untuk melakukan penundaan secara logis. Rasionalisasi yang digunakan oleh prokrastinator adalah "saya sulit memulai", "saya menunggu waktu yang tepat untuk melakukannya", "saya belum memahami secara mendalam tentang materi saya", saya akan mengerjakan skripsi dalam keadaan sepi misalnya dini hari agar bisa fokus" namun pada kenyataannya tidak sesuai dengan pernyataan-pernyataan diatas. Hal ini tercermin menjadi rasa perfeksionisme.

Burka dan Yuen (2008) menyebutkan salah satu faktor yang mempengaruhi munculnya prokrastinansi akademik adalah perfeksionisme. Mereka juga mengklaim bahwa prokrastinator membuat keinginan yang tidak realistis, terhadap diri mereka sendiri. Perfeksionisme yang neurotik dapat mengarah pada prokrastinansi. Menurut Ashby (1999) hal yang nampak adanya kecemasan pada tingkat tinggi, kesendirian, dan kegagalan, sehingga perfeksionisme membuat individu enggan menyelesaikan tugas karena tidak merasa mampu mencapai standar yang tinggi (Lasmono dkk, 2008). Rothblum menyebutkan salah satu penghubung antara perfeksionisme dan prokrastinasi adalah keyakinan yang irrasional.

Perfeksionisme itu sendiri dapat dipahami melalui tiga dimensi, yaitu self oriented perfectionism, other oriented perfectionism, dan socially prescribed perfectionisme (Hewwit \& Flett, 1991). Self oriented perfectionism dicirikan dengan membuat standar dan tujuan yang kaku untuk diri mereka sendiri, dan berusaha keras untuk mencapai kesempurnaan, sementara berusaha untuk menhindari kegagalan. Other oriented 
perfectionism difokuskan pada keyakinan dan harapan seseorang terhadap kemampuan orang lain. Socially prescribed perfectionisme merupakan pemenuhan kebutuhan untuk mencapai standar dan harapan yang diberikan oleh lingkungan sosialnya, terutama yang ditentukan oleh significant others (orang tua, dosen pembimbing, teman bahkan masyarkat).

Snaley dkk (2001) mengatakan dalam penelitiannya mengukur bahwa perfeksionisme dapat berarti fenomena positif maupun negatif. Dalam pengukurannya, Snaley mengatakan terdapat tiga dimensi : pertama, dimensi standar (standards) mengukur sejauhmana individu menetapkan standar yang tinggi untuk diri mereka sendiri. Mereka dengan berhati-hati menyusun item-item di dalamnya untuk mendapatkan hasil bahwa dengan menetapkan standar yang tinggi, berarti mereka memiliki kualitas yang negatif.

Faktanya, para peneliti ini percaya bahwa kemungkinan besar standar yang tinggi adalah hal yang positif untuk dimiliki seseorang. Dimensi kedua, kerapihan (order), meliputi item-item yang mengevaluasi bagaimana kerapihan seseorang dalam hidupnya. Kerapihan ini dapat digambarkan jugasebagai keteraturan (organization), efisiensi, dan sebagainya. Dimensi ini cenderung merepresentasikan aspek positif dari perfeksionisme. Terkahir, dimensi ketidaksesuaian/kesenjangan (discrepancy) merepresentasikan aspek negatif dari perfeksionisme. Dimensi ini mengukur bagian dari perfeksionisme yang berhubungan dengan afek negatif. Sebagian besar item di dalamnya menunjukkan aspek negatif yang timbul ketika tingginya standar seseorang tidak sesuai dengan prestasi yang mereka dapatkan karena pada dasarnya hasil dari yang mereka lakukan adalah substandard dari harapan yang ditentukan. Slaney dkk (2001) menemukan bahwa diskrepansi biasanya muncul di bidang akademik.
Burka dan Yuen (2008) menjelaskan bahwa perilaku prokrastinasi mencangkup dua tahapan dan tahapan pertama adalah adanya dorongan untuk menunda. Dorongan ini muncul sebagai akibat dari suasana hati negatif, perasaan terancam, perasaan tidak nyaman, perasaan bosan, dan perasaan atau kondisi negatif lainnya. Tahapan kedua berkaitan dengan tahapan pertama, yaitu meyakini bahwa jika dengan menunda pekerjaan hasilnya akan lebih baik. Kedua tahapan tersebut melibatkan dua proses, yaitu prokrastinasi aktif dan pasif. Prokrastinasiaktif melibatkan aktivitas lain yang ditujukan untuk menghindari pekerjaan yang harus dikerjakan, seperti memilih untuk melakukan rekreasi daripada menyelesaikan tugas. Sedangkan prokrastinasi pasif dilakukan dengan mencari pembenaran yang tidak tepat, yaitu dengan meyakini bahwa dengan mengerjakan tugas di esok hari hasilnya akan lebih baik karena memiliki waktu untuk mempersiapkan diri terlebih dahulu. Kedua tahapan tersebut melibatkan pengalihan perhatian yang menghabiskan waktu dan tenaga untuk menunda penyelesaian tugas.

Berdasarkan paparan tersebut tentang fenomena yang terjadi pada mahasiswa psikologi yang sedang mengerjakan skripsi, peneliti merasa tertarik untuk mengambil judul "Pengaruh Perfeksionisme Terhadap Prokrastinasi Akademik pada Mahasiswa yang Sedang Mengerjakan Skripsi di Fakultas Psikologi UIN Sunan Gunung Djati Bandung".

Berdasarkan permasalahan yang telah dipaparkandalam latar belakang masalah, maka rumusan masalahnya adalah sebagai berikut: "seberapa besar pengaruh perfeksionisme terhadap prokrastinansi akademik pada mahasiswa yang sedang skripsi di Fakultas Psikologi UIN Sunan Gunung Djati Bandung?

Tujuan dari penelitian ini adalah ingin meneliti besaran pengaruh perfeksionisme terhadap prokrastinasi akademik pada mahasiswa yang sedang 
skripsi di Fakultas Psikologi UIN Sunan Gunung Djati Bandung.

Manfaat teoritis dari penelitian ini adalah untuk memperoleh data empiris tentang perfeksionisme dan prokrastinasi akademik pada mahasiswa khususnya yang sedang mengerjakan skripsi, juga sebagai sumbangan ilmiah pada pengembangan keilmuan psikologi khususnya kajian psikologi pendidikan.Manfaat praktis dari penelitian ini adalah untuk memberikan informasi dan menjadi bahan pertimbangan tentang antisipasi terhadap sebab terjadinya prokrastinasi akademik dalam pengerjaan skripsi.

\section{METODE PENELITIAN}

Metode penelitian ini mengguna-kan pendekatan kuantitatif dengan rancangan penelitian non-experimental dengan metode kausalitas. Metode ini digunakan untuk mengidentifikasi bagaimana hubungan antara dua atau lebih variabel (Sudjana, 2005). Hubungan ini disebut hubungan fungsional yang dinyatakan dalam sebuah persamaan matematika yaitu persamaan regresi. Hubungan kausalitas menunjukkan adanya sebab dan akibat antar variabel. Dalam analisis regresi, dibedakan dua jenis variabel, yaitu variabel bebas $(X)$ sebagai faktor yang digunakan oleh peneliti untuk menetapkan hubungan antara faktor tersebut dengan fenomena yang sedang dikaji, serta variabel terikat $(Y)$ sebagai faktor yang dipengaruhi oleh variabel bebas.

Dalam penelitian ini, yang menjadi variabel bebas adalah Perfeksionisme, dan yang menjadi variabel terikat adalah Prokrastinansi Akademik. Secara skematik rancangan penelitian digambarkan sebagai berikut:

Gambar 3.1. skema Rancangan penelitian korelasi sebab akibat

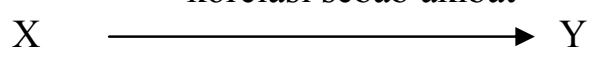

Ket: $\mathrm{X}=$ Perfeksionisme ; $\mathrm{Y}=$ Prokrastinasi Akademik

\section{Variabel Penelitian \\ Variabel Pertama $(X)$}

Variabel pertama dalam penelitian ini adalah perfeksionisme. Secara konseptual Perfeksionisme menurut Hewwit dan Flett (1992) adalah keinginan untuk mencapai kesempurnaan, yang diikiti oleh standar yang tinggi, standar yang tinggi untuk orang lain, dan percaya bahwa orang lain punya pengharapan kesempurnaan untuk dirinya. Definisi Operasional Perfeksionisme dalam penelitian ini meliputi 3 dimensi:

a) Standars: sejauhmana individu menetapkan standar yang tinggi untuk diri mereka sendiri

b) Order: yang mengevaluasi bagaimana kerapihan seseorang dalam hidupnya. Kerapihan ini dapat digambarkan juga sebagai keteraturan (organization), efisiensi, dan sebagainya.

c) Discrenpansy: menunjukkan aspek negatif yang timbul ketika tingginya standar seseorang tidak sesuai dengan prestasi yang mereka dapatkan karena pada dasarnya hasil dari yang mereka lakukan adalah substandard dari harapan yang ditentukan.

Tingkat kecenderungan perfeksionisme dilihat dari besarnya skor yang diperoleh dari skala perfeksionisme mahasiswa. Semakin tinggi skor total yang diperoleh, semakin tinggi pula kecenderungan perfeksionismenya. Sebaliknya semakin rendah skor yang diperoleh, menunjukkan semakin rendah pula kecenderungan perfeksionismenya.

Skala Perfeksionisme ini merupakan diukur melalui perolehan skor APS-R (Almost Perfect Scale Revised). Skor $\leq 68,535$ menunjukkan tingkat perfeksionisme yang rendah, skor 68,585 - 87,985 bermakna sedang dan skor $\geq$ 87,985 bermakna tinggi.

Variabel Kedua ( $Y$ )

Variabel kedua dalam penelitian ini adalah prokrastinasi akademik skripsi. Definisi konseptual Prokrastinasi akademik adalah kecenderungan individu dalam merespon tugas sekolah yang 
dihadapi dengan mengulur-ulur waktu untuk memulai maupun menyelesaikan kinerja secara sengaja untuk melakukan aktivitas lain (Solomon dan Rothblum : 1984). Sedangkan prokrastinasi akademik skripsi adalah seberapa frekuensi dan intensitas tingkah laku seseorang untuk menunda memulai maupun menyelesaikan skripsi secara keseluruhan.

Definisi Operasional Prokrastinassi akademik skripsi dalam penelitian ini adalah penundaan subjek yang ditunjukan pada :

1) adanya penundaan dalam memulai menyelesaikan kinerja dalam menghadapi tugas skripsi,

2) adanya kelambanan dalam mengerjakan tugas skripsi,

3) adanya kesenjangan waktu antara rencana dengan kinerja aktual dalam mengerjakan tugas skripsi,

4) adanya kecenderungan untuk melakukan aktivitas lain yang dipandang lebih mendatangkan hiburan dan kesenangan daripada mengerjakan skripsi.

Tingkat prokrastinasi akademik dilihat dari besarnya skor yang diperoleh dari skala prokrastinasi akademik pengerjaan skripsi pada mahasiswa. Semakin tinggi skor total yang diperoleh, semakin tinggi pula kecenderungan prokrastinasi akademik dalam pengerjaan skripsinya. Sebaliknya semakin rendah skor yan diperoleh, menunjukkan semakin rendah pula kecenderungan untuk melakukan prokrastinasi akademik dalam pengerjaan skripsinya.

Prokracstinasi akademik ini diukur melalui perolehan skor PASS (Procrastination Assessment Scale Student). Skor $\leq 102,23$ menunjukkan tingkat moral integrity yang rendah, skor 102,23 - 144, 83 bermakna sedang dan skor $\geq 144,83$ bermakna tinggi.

\section{Subjek Penelitian}

Pada penelitian ini, peneliti menggunakan penelitian populasi, karena jumlah anggota sedikit, dimungkinkan semua anggota populasi yang diteliti sehingga semua anggota populsi dijadikan subjek penelelitian. Penelitian populasi yaitu penelitian ang dilakukan terhadap lingkup luas dengan semua subjek penelitian dan kesimpulannya berlaku bagi semua subjek penelitian tersebut (Arikunto, 2002).

Adapun kriteria subjek dalam penelitian ini adalah:

1. Masih berstatus sebagai mahasiswa S1 pada Fakultas Psikologi UIN Sunan Gunung Djati Bandung yang masih aktif.

2. Mahasiswa dalam rentang masa dewasa yang berada antara usia 20 tahun sampai awal 30 tahun.

3. Sedang melakukan pengerjaan skripsi yang melebihi 2 semester dari pengambilan mata kuliah skripsi.

Populasi dalam penelitian ini adalah mahasiswa Fakultas Psikologi yang masih aktif sampai semester 14 dan sedang mengerjakan skripsi. Sehingga terlihat range angkatannya antara 2005-2007 UIN Sunan Gunung Djati Bandung yang berjumlah 38 orang.

\section{Teknik Pengumpulan Data \\ Metode dan Instrumen}

Metode yang digunakan dalam penelitian ini adalah metode kuesioner. Sedangkan Instrumen yang digunakan adalah skala psikologi. Cronbach (dalam Azwar, 2008) menjelaskan bahwa skala psikologi memiliki beberapa karakteristik diantaranya: pertama, stimulusnya yang berupa penyataan-pernyataan, berisi indikator-indikator atribut yang hendak diukur sehingga pernyataan tersebut tidak secara langsung mengungkap atribut yang diukur dan responden tidak mengetahui arah pertanyaan tersebut, namun jawaban responden mencerminkan kepribadiannya.

Kedua, skala ini berisi item-item yang mencerminkan indikator dari atribut yang diukur. Kepribadian subjek dapat disimpulkan bila seluruh item dalam skala direspon. Ketiga, respon yang diberikan tidak ada yang benar ataupun salah. Seluruh jawaban dapat diterima apabila responden mengisinya secara jujur, hanya 
saja jawaban setiap subjek yang berbeda akan diinterpretasikan berbeda pula.

Skala alat ukur kedua variabel dalam penelitian ini berskala likert. Likert (dalam Friedenberg, 1995), menjelaskan bahwa skala ini adalah skala likert yang digunakan untuk mengukur sikap seseorang, yang isi datanya merupakan data ranking atau ordinal. Skala ini berisi pernyataan-pernyataan yang mencerminkan sikap postitif dan negatif. Pernyataanpernyataan tersebut kemudian diletakan oleh responden pada skala ordinal yang bergerak yang mencerminkan "sangat tidak setuju" sampai pada "sangat setuju. Analisis yng digunakan dalam penelitian ini adalah analisis regresi. Pada keumumannya regresi menggunakan skala interval (Bungin, 2010) namun dalam sebuah peneltian disebutkan bahwa data statistik regresi dapat digunakan pada data ordinal (Norman, 2010). Carifo dan Perla (2008) mengemukakan bahwa item-item atau pernyataan Likert memang ordinal, namun skala Likert, yang berisi kumpulan seluruh item, bisa menjadi interval (dalam Norman, 2010).

\section{Alat ukur perfeksionisme}

Pada alat ukur perfeksionisme, peneliti mengadapatasi dari alat ukur yang dibuat oleh Snaley at all (1992), yang bernama Almost Perfect Scale - Revised (APS-R). Alat ukur peokrsastinansi akademik skripsi diberikan berupa bentuk kuesioner yang dimodifakasi dari Procrastination Assessment Scale Student yang di susun oleh Solomon dan Rothblum (1984) yang itemnya diadatasi dari penelitian yang dilakukan oleh Utami (2009), dengan menggunakan skala likert, kemudian diinterpretasikan sebagai skala interval. Masing-masing aspek diwakili oleh pernyataan-pernyataan yang menjaring prokrastinansi akademik skripsi.

Oleh karena data yang didapatkan dalam kedua skala ini berbentuk interval, maka pengujian daya beda item dilakukan dengan menggunakan korelasi product- moment Pearson (dengan bantuan program SPSS versi 16.0).

Berdasarkan hasil pengolahan, alat ukur APS-R memiliki nilai koefisien reliabilitas sebesar $r_{x x}=0,781$. Sedangkan alat ukur PASS memiliki nilai koefisien reliabilitas sebesar $r_{x x}=0.918$. Nilai koefisien ini memiliki makna bahwa sebesar 78,1\% dari seluruh skor APS-R dapat menunjukan perbedaan antar responden dan sebesar $21,9 \%$ persen yang tampak pada perbedaan skor disebabkan karena kesalahan dalam pengukuran. Sama halnya dengan PASS, 91,8 \% dari seluruh skor PASS dapat menunjukan perbedaan antara subjek penelitian, dan $8,2 \%$ persen diantaranya menunjukan variasi eror dalam pengukuran. Bila diinterpretasikan ke dalam makna koefisiennya, kedua alat ukur ini sama-sama memiliki reliabilitas yang sangat tinggi.

\section{Hipotesis Statistik}

Hipotesis yang ditetapkan dalam penelitian ini adalah sebagai berikut:

$\mathbf{H}_{0}: \boldsymbol{p}=\mathbf{0}$, terdapat pengaruh yang signifikan perfeksionisme terhadap prokrastinasi akademik yang sedang mengerjakan skripsi.

$\mathbf{H}_{1}: \boldsymbol{\rho}>\mathbf{0}$, tidak terdapat pengaruh signifikan perfeksionisme terhadap prokrastinasi akademik yang sedang mengerjakan skripsi.

\section{PEMBAHASAN}

Pembahasan dalam penelitian ini akan mengacu pada analisis statistik inferensial. Sebagaimana telah dikemukakan di awal, bahwa penelitian ini bertujuan untuk melihat seberapa besar pengaruh perfeksionisme terhadap prokrastinasi akademik pada mahasiswa yang sedang mengerjakan skripsi.

Berdasarkan pengolahan data melalui analisis statistik diperoleh hasil bahwa $\mathrm{H} 0$ yang diajukan diterima dan $\mathrm{H} 1$ di tolak, yang berarti bahwa tidak terdapat pengaruh yang signifikan antara perfeksionisme dengan prokrastinasi akademik pada mahasiswa yang sedang 
mengerjakan skripsi di Fakultas Psikologi UIN Sunan Gunung Djati Bandung. Berdasarkan uji analisis regresi diperoleh koefisien korelasi dengan F-reg $=2,502$ signifikansi 0,122>0,05, dengan koefisien determinasi $\mathrm{r}^{2}$ sebesar 0,065 atao $6,5 \%$ dengan $t_{\text {hitung }}=1,582<t_{\text {tabel }}=1,684$.

Dengan menggunakan median dari data yag diperoleh, dapat dilihat bahwa mahasiswa angkatan 2005-2007 Fakultas Psikologi UIN Sunan Gunung Djati Bandung yang sedang mengerjakan skripsi, sebanyak 5 orang $(13,16 \%)$ memiliki perfeksionisme yang tinggi, sebanyak 27 orang $(71,05 \%)$ memiliki perfeksionisme sedang, dan 6 orang $(15,79 \%)$ memiliki perfeksionisme rendah.

Berdasarkan katregorisasi subjek perfeksionisme, $71,05 \%$ subjek berada dalam kategori sedang. Hal ini menunjukkan bahwa perfeksionisme subjek masih dalam keadaan wajar dan tidak mengarah kepada perfeksionisme negatif/neurotik berdasarkan pengertian perfeksionis menurut Hewit dan Flett (1991).

Hasil penelitian ini tidak sejalan sejalan dengan pernyataan yang dikemukakan oleh Burka \& Yuen (2008) bahwa salah satu faktor yang memengaruhi munculnya perilaku prokrastinasi akademik adalah perfeksionisme. Burka dan Yuen mengklaim bahwa prokrastinator membuat keinginan yang tidak realistis terhadap diri mereka sendiri. Burka dan Yuen melihat prokrastinator banyak mengekspresikan karakteristik secara kognitif yang berhubungan dengan perfeksionisme, misalnya kecenderungan untuk mendukung pentingnya continual success (sukses yang berkelanjutan). Seseorang yang perfeksionis menuntut segalanya serba sempurna dan terkadang memiliki harapan yang tidak realistik. Perfeksionisme membuat seseorang enggan menyelesaikan tugas karena merasa tidak mampu mencapai standar.

Ketidaksesuaian antara perhitungan statistik dengan pernyataan tersebut dikarenakan adanya pengaruh statistical regression, yaitu terlalu heterogen respon mahasiswanya. Jika di hitung secara statistik hasil tersebut tidak dapat menyatakan adanya pengaruh perfeksionisme terhadap prokrastinasi akademik skripsi, karena hasil tersebut tidak mengikuti pola perhitungan yang seharusnya untuk suatu korelasi. Oleh karena itu karena adanya pengaruh statistical regression, maka perhitungan secara statistik tidak dapat dijadikan pegangan dalam menyimpulkan pengaruh pada kedua variabel tersebut.

Dari hasil analisis regresi yang menunjukan bahwa tidak terdapat pengaruh antara perefeksionisme terhadap prokrastinasi akademik skripsi, jika dilihat dari gambaran umum deskriptif perfeksionisme dan prokrastinasi akademik skripsi, skor yang muncul adalah bahwa gambaran keduan variabel tersebut berapa di kategori sedang dengan perolehan persentase $71,55 \%$ untuk perfeksionisme dan $68,42 \%$ untuk prokrastinasi akademik yang sedang mengerjakan skripsi. Jadi dari hasil kedua variabel tersebut hanya memiliki hubungan yang lemah.

Namun apabila di tinjau dari aspekaspek perfeksionisme itu sendiri, hanya ada satu yang mempunyai pengaruh yang signifikan terhadap prokrastinasi akademik yang sedang mengerjakan skripsi. Aspek yang dimaksud adalah aspek diskrenpansi yaitu yang menunjukkan aspek negatif yang timbul ketika tingginya standar seseorang tidak sesuai dengan prestasi yang mereka dapatkan karena pada dasarnya hasil dari yang mereka lakukan adalah substandard dari harapan yang ditentukan. Hal ini sesuai dengan pernyataan yang dikemukakan oleh Snaley dkk (2001) dimensi diskrenpansi sering muncul di area akademik.

Dapat dijelaskan bahwa ketika seseorang tidak dapat mencapai standar atau harapan yang telah ditentukan dalam hal prestasinya, maka orang itu akan melakukan coping, tetapi coping yang yang dilakukan tidak rasional yang akhirnya mereka melakukan penundaan 
atau prokrastinasi, dalam hal ini adalah prokrastinasi akademik.

\section{SIMPULAN}

Berdasarkan hasil penelitian dan pembahasan yang telah dijelaskan sebelumnya, maka diperoleh kesimpulan bahwa tidak terdapat pengaruh yang signifikan antara perfeksionisme terhadap prokrastinasi akademik pada mahasiswa yang sedang mengerjakan skripsi di Fakultas Psikologi UIN Sunan Gunung Djati Bandung.

\section{Saran}

Dengan memperhatikan segala keterbatasan penelitian ini, peneliti mengajukan beberapa hal atau saran kepada beberapa pihak untuk dapat dijadikan sebagai bahan pertimbangan, diantaranya kepada mahasiswa. Mahasiswa sebaiknya mengomunikasikan hambatan yang dialami selama pengerjaan skripsi dan untuk tidak menjauhi dari tugas-tugas ketika mengalami hambatan tersebut.

Hal tersebut dilakukan agar mahasiswa tidak terfokus pada perasaan cemas dan takut gagal yang membuat dirinya memilih untuk menunda untuk menyelesaikan skripsi, tetapi mengutamakan penyelesaian masalah pengerjaan skripsinya. Selain itu, agar mahasiswa tidak melarikan diri dengan mengerjakan aktivitas lain yang tidak ada relevansinya dengan pengerjaannya skripsi, meskipun ditemukan hambatan selama proses pengerjaannya.

\section{DAFTAR PUSTAKA}

Arikunto, S. (2002). Prosedur Penelitian. Jakarta: Rineka Cipta.

Azwar, Saefuddin. (2008). Penyusunan Skala Psikologi. Yogyakarta: Pustaka Pelajar.

Bungin, Burhan. (2010). Metodologi Penelitian Kuantitatif: Komunikasi, Ekonomi, dan Kebijakan Publik Serta Ilmu-Ilmu Sosial Lainnya. Jakarta: Kencana.
Burka J. B. \& Yuen L. M. (2008). Procrastination: Why You Do it, What to Do About It. New York: Persues Books.

Champion, Dean J. (1981). Basic Statistics for Social Research. United States of America: Macmillan Publishing.

Knaus. W. (2002). The Procrastination Workbook. New Harbinger Publications, inc.

Ferrari, J. R., \& johnston, J., \& McCown. (1995). Procrastination And Task Avoidance. New York: Plenum Press.

Flett, G.L., Hewitt, R.L., Blankstein, K.R., \& Koledin, S. (1991). Dimensions of perfectionism and irrational thinking. Journal of RationalEmotive \& Cognitive-Behavior Therapy, 9 (3).

Friendenberg, L. (1995). Psychological Testing Design, Analysis, And Use. The University Of North Caroline at Asheville.

Hewitt, P. \& Flett, G. (1991). Dimensions Of Perfectionism in Unipolar Depression. Journal of Abnormal Psychology 100 (1): 98-101. doi: 10.1037/0021-843X.100.1.98, PMID 2005279.

Hewitt, P. L. \& Flett, G., L. (1992). Perfectionism and Multiphasic Personality Inventory (MMPI) indices of personality disorder.

Hurlock, Elizabeth. (1980). Psikologi Perkembangan. Jakarta: Erlangga.

Lasmono, Hari K., Nanik., Gunawinata, Vensi Anita Ria. (2008). Perfeksionisme, Prokrastinasi Akademik, Dan Penyelesaian Skripsi Mahasiswa. Anima Indonesian Psychologiocal Journal, Vol 23, No. 3, 256-276.

Norman, Geoff. (2010). Likert Scales, Levels Of Measurement And The "Laws" of Statistics. Adv in Health Sci Educ, Received: 22 January 2010 / Accepted: 22 January $2010 . \quad$ DOI 10.1007/s10459-010-9222-y 
Papalia, Diane, et all. (2002). Human Developmen (Psikologi perkembangan): Bagian V s/d IX. Jakarta: Perdana Media Gruop.

Pullen, Frances Janelle. (2003). Perfectionism, procrastination, and other self-reported barriers to completing the doctoral dissertation. University Of Lowa.

Purwanto, Yadi. (2007). Psikologi Kepribadian Integritas Nafsiyah dan Aqliyah Perspektif Psikologi Islami. Bandung: Refika Aditama.

Santoso, Singgih. (2001). SPSS Versi 10. Jakarta: PT Alex Media Komputindo.

Sarwono, Jonathan. (2009). Statistik Itu Mudah Panduan Lengkap Untuk Belajar Komputasi Stastistik Menggunakan SPSS 16. Yogyakarta: Andi Yogyakarta.

Snaley, R. B., \& Johnson, D. G. (1992). The Almost Perfect Scale. Unpublished Manuscript, Pennsylvania State University.

Slaney, R.B., Rice, K.G., Mobley, M., Trippi, J. \& Ashby, J.S. (2001). The Almost Perfect Scale Revised. Measurement and Evaluation in Counseling and Development $\mathbf{3 4}$ (3): 130-145.
Siegel, Sidney. (1992). Nonparametric Statistics for the Behavioral Science (edisi terjemah). Jakarta: PT Gramedia Pustaka Utama.

Solomon, L. J. \& Rothblum, E. D. (1984). Academic Procrastination: Frequency and Cognitif Behavoiral Correlates. Journal of Counseling Psychology, Vol 31. 503-509.

Sudjana. 1996. Metoda Statistika edisi keenam. Bandung: Tarsito.

Utami, Mega Riksa. 2009. Hubungan Antara Motivasi Berprestasi Dengan Prokartinasi Tugas Skripsi (Studi Terhadap Mahasiswa Yang Sedang Menyusun Skripsi Pada Angkatan 2003-2005 Fakultas Psikologi UIN Sunan Gunung Djati Bandung). Skripsi tidak diterbitkan : Fakultas Psikologi UIN Sunan Gunung Djati Bandung. 